\title{
Four Types of Undergraduate Library Users, Based on Their Profile of Library Use, Knowledge and Perceptions
}

\author{
K.G.D.A. Karunanayake \\ Department of Academic Services. Library \\ Fiji National University, Nasinu, Suva, Fiji Islands \\ anura.karunanayake@fnu.ac.fj \\ Haruki Nagata \\ Professor Emeritus \\ University of Tsukuba, Japan \\ nagata.haruki.ff@u.tsukuba.ac.jp
}

\begin{abstract}
Introduction. This study sought to identify common factors of library use, knowledge and perceptions, and clusters of library users with similar profiles on these factors, reflecting different patterns of library use behaviour.

Method. A questionnaire was designed to collect data relating to five aspects of library use, knowledge and perceptions: 1. Library search skills/confidence, 2. Familiarity with and use of library resources, 3 . Familiarity with and use of library services, 4 . Familiarity with the library organization system, 5 . Perceptions of library searching experience. A survey was conducted on a group of undergraduate students in Japan.

Analysis. Principal components analysis was applied to identify the principal components of library use/knowledge/perception, while cluster analysis found different user groups with different profiles of library use/knowledge/perception. Results. Four clusters of undergraduate library users were identified as ineffective library users, effective library users, ineffective but positive users, and selfsufficient users.
\end{abstract}

\section{INTRODUCTION}

Students behave differently during information searching in libraries according to their patterns of library use, knowledge and perceptions. Because of these differences, some students appear to be better than others in using libraries. The reasons are multifaceted and not limited to a single variable or discrete entity. There is a need to identify these variables which affect individual behaviour in libraries. However, there are many different variables to consider such as discipline, gender and academic years of learning that may affect the students' library use. The variables of library use, search skills, knowledge of library resources/services, and perceptions/attitudes towards the library are highly correlated at multiple levels with students in libraries. Identifying these correlations provides a basis for identifying groups of students with similar profiles and needs, so that the library can tailor services and resources for different groups to improve the effectiveness of their library use and learning outcomes. 
The objectives of this study were:

1. To identify the principal components or factors underlying undergraduate students' library use, knowledge/skills and perceptions/attitudes;

2. To identify groups and types of undergraduate library users with similar profiles of library use/knowledge/perceptions.

This study focussed on the students' profiles in terms of their information searching behaviour/skills in the libraries and the potential for enhancing their information skills. This study limited the students' library use/knowledge/perception to five categories:

1. library search skills/confidence,

2. familiarity with and use of library resources,

3. familiarity with and use of library services,

4. familiarity with the library organization system, and

5. perception of library searching experience.

Construction and limitation of the five categories of library use/knowledge/perception were based on the authors' professional experience and practical problems we encountered on a day-to-day basis overseeing the use of libraries. Participants in the survey were limited to undergraduate students at the School of Medicine and the School of Social and International Studies at the University of Tsukuba, Japan.

\section{PREVIOUS STUDIES}

\section{Library Use by Undergraduates and Others}

There is a broad spectrum of research studies on library user behaviour which cover a variety of library use activities. Students behave differently during information searches because of their programmes of study (undergraduate or graduate), areas of discipline (medicine, social science, arts, engineering, etc.), academic years (junior or senior), gender (male or female), emotional experiences (certainty or uncertainty) and cognitive context (knowledge and skill, etc.).

Palmer (1991) found a few indications of the differences across discipline lines in the process of information searching among biochemists, entomologists, and statisticians working at an agricultural research station and university medical library. Five specific user groups such as "non-seekers', "wide rangers', "unsettled or self-conscious seekers', "confident collectors' and "hunters' were found by cluster analysis, indicating coherent patterns of differentiation in information search by disciplines. The results appear to show that information search behaviour was highly affected by the discipline areas, but the study focused on discipline areas, not individual use activities. In a discipline context, library use patterns may manifest differences at the surface level, but examination of usage context might show deep differences among individuals even within the discipline context.

Hiller (2002) studied patterns of library use among students from different disciplines. Findings reflected the priorities which students chose. Though the results showed differences among disciplines, they might reflect students' subjective preferences, not their actual use patterns. It could be assumed that Hiller's findings of differences in search patterns among disciplines do not account for individual use attributes.

Whitmire (2001), in a longitudinal study of undergraduates' academic library experience, assumed that differences in library use can be attributed to students' placement in different academic years. The study addressed eleven library experience variables. Some experiences increased during each successive year of the study. This study identified several 
patterns from eleven variables in library use that contribute to the differences for the remainder of the students' academic years. Some areas of knowledge development increased during the consecutive academic years. Examination of library use was limited to three academic years.

Atkins and Ashcroft (2004) aimed to understand information search skill, which they defined as "the ability to formulate information needs, locate, retrieve, and evaluate information." The survey concentrated on a comprehensive measurement of information skill and found that there was a difference between native and non-native speakers in their searching abilities. This study sought to determine whether or not there are discrepancies within the same student groups with similar library search abilities.

The study of "the relative effects of knowledge, interest and confidence in assessing relevance" examined how different aspects of searchers' contexts, in particular their knowledge of a search topic, their interest in the search topic, and their confidence in assessing relevance for a topic, affected the relevance of judgments made and the searchers' ability to predict which documents they will assess as being relevant (Ruthven, Baillie \& Elsweiler, 2007). The study found searchers with high self-declared knowledge regarding a search topic, high interest in the search topic or high confidence in their judgments of relevance made more document selections relevant to a search than searchers with lower topical knowledge, interest and confidence.

A study by Nagata, Toda and Kytomaki (2007) found that undergraduates visited the library for various reasons. The objectives of the study were to understand students' usage patterns of the library and their educational outcomes. Though the study focused on library use and educational outcomes, the findings regarding students' library use are relevant to this study. The identification of students' patterns came from usage context. Learners, strollers, extended users or socializers, place and personal computer users generally showed similarities, thus creating common groups. This study showed that students were not identical in their usage contexts, and the relationship between their patterns of usage and educational outcomes. Similarly, Goodall and Patterns (2013) found that academic library non/low use had a strong relationship with undergraduate student achievement, while Stone and Collins (2013) found library usage and demographic characteristics of undergraduate students in a British university from a demographic point of view. Soria, Fransen and Nackerud (2013) elaborated on library use and undergraduate student outcomes focusing on new evidence for student retention and academic success. Though students' use of libraries have been seen from diverse perspectives as discussed above, this paper will set up clear categorizations of factors that provide clearer insights into students' usage in the context of libraries.

\section{RESEARCH METHOD}

The questionnaire consisted of twenty statements listed in Table 1, each representing an aspect of library use, knowledge or perception. These were grouped into five aspects:

1. Library search skills/confidence: clarity of information needs (whether the students start information search with potential or desired information aim); search planning; teacher directed search (whether students search for teacher-recommended information); searching confidence.

2. Familiarity with and use of library resources: awareness of digital resources; known item search; use of digital resources; use of familiar resources (whether they adopted previously used sources or were willing to use new sources. 
Table 1. Conceptual framework of library use, knowledge and perception

\begin{tabular}{|c|c|c|}
\hline Category & $\begin{array}{l}\text { Aspect of library use/ } \\
\text { knowledge/perception }\end{array}$ & Questionnaire item \\
\hline \multirow[t]{4}{*}{$\begin{array}{l}\text { Library search } \\
\text { skills/confidence }\end{array}$} & $\begin{array}{l}\text { 1. Clarity of information } \\
\text { needs }\end{array}$ & $\begin{array}{l}\text { I begin my library search with an exact and firm } \\
\text { idea of my information need. }\end{array}$ \\
\hline & 2. Search planning & $\begin{array}{l}\text { I usually setup a search strategy to look for } \\
\text { information. }\end{array}$ \\
\hline & 3.Teacher directed search & $\begin{array}{l}\text { I come to the library to search for information } \\
\text { recommended by teachers }\end{array}$ \\
\hline & 4. Searching confidence & $\begin{array}{l}\text { I am quite competent when using search terms in } \\
\text { the library }\end{array}$ \\
\hline \multirow[t]{4}{*}{ Library resources } & $\begin{array}{l}\text { 5. Awareness of digital } \\
\text { resources }\end{array}$ & $\begin{array}{l}\text { I know of the availability of digital documents in } \\
\text { the library. }\end{array}$ \\
\hline & $\begin{array}{l}\text { 6. Amount of known } \\
\text { item search }\end{array}$ & $\begin{array}{l}\text { Most of my searches are of author and title of a } \\
\text { book. }\end{array}$ \\
\hline & $\begin{array}{l}\text { 7. Use of digital } \\
\text { resources }\end{array}$ & I am good at using digital resources. \\
\hline & $\begin{array}{l}\text { 8. Use of familiar } \\
\text { resources }\end{array}$ & $\begin{array}{l}\text { I frequently select the resources which I am } \\
\text { familiar with, rather than look for new ones. }\end{array}$ \\
\hline \multirow[t]{4}{*}{ Library services } & $\begin{array}{l}\text { 9. Use of journal articles } \\
\text { service }\end{array}$ & $\begin{array}{l}\text { I look at journal articles when searching for } \\
\text { information in a current research area. }\end{array}$ \\
\hline & $\begin{array}{l}\text { 10. Familiarity with ILL } \\
\text { services }\end{array}$ & $\begin{array}{l}\text { I know that an Inter-library Loan service is } \\
\text { available in my library. }\end{array}$ \\
\hline & $\begin{array}{l}\text { 11. Utilizing of } \\
\text { assistance services }\end{array}$ & $\begin{array}{l}\text { I consult a librarian when I have difficulty in } \\
\text { finding information. }\end{array}$ \\
\hline & $\begin{array}{l}\text { 12. Perception of } \\
\text { information literacy } \\
\text { programs }\end{array}$ & $\begin{array}{l}\text { Information literacy programs in the library have } \\
\text { increased my knowledge of how to locate needed } \\
\text { resources }\end{array}$ \\
\hline \multirow[t]{4}{*}{$\begin{array}{l}\text { Library organization } \\
\text { system }\end{array}$} & $\begin{array}{l}\text { 13. Image of the } \\
\text { information } \\
\text { provider }\end{array}$ & $\begin{array}{l}\text { Library services provide adequate information for } \\
\text { my search. }\end{array}$ \\
\hline & $\begin{array}{l}\text { 14. Amount of library } \\
\text { self-browsing }\end{array}$ & $\begin{array}{l}\text { Most materials I need are found browsing through } \\
\text { the bookshelves. }\end{array}$ \\
\hline & $\begin{array}{l}\text { 15. Familiarity with } \\
\text { organization of the } \\
\text { library }\end{array}$ & $\begin{array}{l}\text { I know the entire layout and material } \\
\text { arrangements in the library. }\end{array}$ \\
\hline & $\begin{array}{l}\text { 16. Familiarity with } \\
\text { indexing and reference } \\
\text { tools }\end{array}$ & $\begin{array}{l}\text { Bibliographies, references, indexers and abstracts } \\
\text { are useful for me when gathering Information } \\
\text { from the documents I find. }\end{array}$ \\
\hline \multirow[t]{3}{*}{$\begin{array}{l}\text { Perception of } \\
\text { searching experience }\end{array}$} & $\begin{array}{l}\text { 17. Perception of self- } \\
\text { learning }\end{array}$ & $\begin{array}{l}\text { Each of the searches increased my knowledge } \\
\text { on how to access information. }\end{array}$ \\
\hline & $\begin{array}{l}\text { 18. Perception of library } \\
\text { adequacy }\end{array}$ & $\begin{array}{l}\text { I know the library has enough collection for my } \\
\text { requests. }\end{array}$ \\
\hline & $\begin{array}{l}\text { 19. Satisfaction with } \\
\text { relevance of materials } \\
\text { 20. Satisfaction with } \\
\text { relevance information }\end{array}$ & $\begin{array}{l}\text { I have succeeded in finding information materials } \\
\text { for my search (Material satisfaction). } \\
\text { About } 80 \% \text { of my searches end with } \\
\text { comprehensible, credible, and relevant } \\
\text { information for my needs (Information } \\
\text { satisfaction). }\end{array}$ \\
\hline
\end{tabular}


3. Familiarity with and use of library services: use of journal articles service, utilizing of assistance services; perception of information literacy program; image of the information provider.

4. Familiarity with the library organization system: image of the library; amount of library self-browsing; familiarity with organization of the library; lack of familiarity with indexing and reference tools.

5. Perception of library searching experience: perception of self-learning, positive perception of the library; satisfaction with relevance of materials found (materials satisfaction); satisfaction with relevance of information found (information satisfaction).

All of the twenty statements were designed as positive statements with a seven-point response scale from SA-Strongly Agree, A-Agree, QA-Quite Agree, UD-Undecided, QDQuite Disagree, D-Disagree, SD - Strongly Disagree.

The participants consisted of a non-random sample of undergraduate students. The questionnaire was administered among the students present at the library information desk of the School of Medicine and the School of Social Sciences and International Studies during three time periods (10.00 am to $12.00 \mathrm{pm}, 15.00 \mathrm{pm}$ to $17.00 \mathrm{pm}$, and $19.00 \mathrm{pm}$ to $21.00 \mathrm{pm}$ ) over three consecutive days.

Two hundred and ninety-one students affiliated with the School of Medicine and the School of Social Sciences and International Studies responded. Thirty nine students who did not respond to several statements, three students who failed to mention their academic years, seven who were attached to other schools, and nineteen who were registered in graduate courses were dropped from the dataset. Out of 291 respondents only 222 were selected. Of these, $72 \%$ (160) were from the School of Medicine and 28\% (62) were from the School of Social and International Studies.

\section{RESULTS}

\section{Extracting Principal Components From the Questionnaire Responses}

The responses collected were subjected to principal components analysis. The derived components were rotated using the oblique promax rotation. Six components were derived, representing patterns of relationship among the variables. A Kaiser Mayer-Olkin (KMO) measure of sampling adequacy was applied to test the validity of the correlation and adequacy. Sampling adequacy is good (KMO value of 0.826). Bartlett's Test of Sphericity yielded a significant result, indicating that there are correlations in the dataset that are appropriate for principal components analysis.

Six components with an eigenvalue greater than 1.0 accounting for $61.8 \%$ of the variance in the data were extracted. The first component was heavily loaded on (i.e. highly correlated with) six variables. The second component was loaded on four variables, the third component on two variables, the fourth component on three variables, the fifth component on two, and the sixth component on three variables, as indicated in Table 2.

Component 1 "Proficient search capability" has high positive loadings with six variables: impact of the search experience in accessing the information, ability to setup search strategy, awareness of library layout, efficacy of library search, needs of current information, and good awareness of one's need. It accounted for $29 \%$ of the variance in the dataset. 
Table 2. Factor loadings for the six principal components derived from the 20 variables representing different aspects of library use, knowledge and perception

\begin{tabular}{|c|c|c|c|c|c|c|}
\hline \multirow[b]{2}{*}{20 variables } & \multicolumn{6}{|c|}{ Components } \\
\hline & 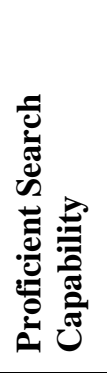 & 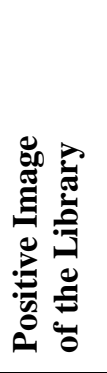 & 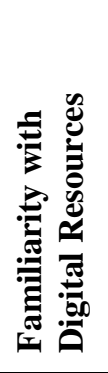 & 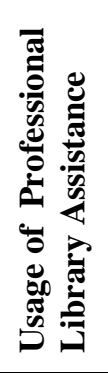 & 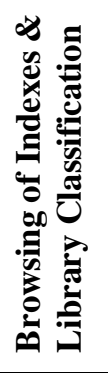 & 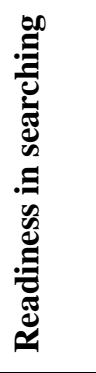 \\
\hline $\begin{array}{l}\text { 17. Each of the searches increased my } \\
\text { knowledge on how to access } \\
\text { information.(Personal knowledge) }\end{array}$ & .813 & .141 & -.141 & .035 & -.087 & -.011 \\
\hline $\begin{array}{l}\text { 2. I usually setup a search strategy to look } \\
\text { for information.(Efficiency of library search) }\end{array}$ & .768 & .026 & -.042 & .087 & .021 & .069 \\
\hline $\begin{array}{l}\text { 15. I know the entire layout and material } \\
\text { arrangements in the library. (Understanding } \\
\text { of system layouts) }\end{array}$ & .611 & -.126 & .059 & .105 & .179 & .126 \\
\hline $\begin{array}{l}\text { 4. I am quite competent when using search } \\
\text { terms in library. (Searching strategy) }\end{array}$ & .577 & .291 & .114 & -.223 & -.048 & -.175 \\
\hline $\begin{array}{l}\text { 9. I look at journal articles when searching } \\
\text { for information in current research areas. } \\
\text { (Currency of resources) }\end{array}$ & .571 & -.188 & .304 & .157 & .061 & .026 \\
\hline $\begin{array}{l}\text { 1. I begin my library search with exact and } \\
\text { firm ideas of my informational needs. } \\
\text { (Information needs situation) }\end{array}$ & .437 & .349 & .078 & -.325 & .005 & .090 \\
\hline $\begin{array}{l}\text { 13. Library services provide adequate } \\
\text { information for my search. (Image of the } \\
\text { information provider) }\end{array}$ & -.145 & .793 & -.020 & .085 & .006 & .212 \\
\hline $\begin{array}{l}\text { 18. I know the library has enough collection } \\
\text { for my requests. } \\
\text { (Evaluation of the resources) }\end{array}$ & .109 & .758 & -.064 & .192 & -.170 & -.070 \\
\hline $\begin{array}{l}\text { 20. About } 80 \% \text { of my searches end with } \\
\text { comprehensible, credible, and relevant } \\
\text { information for my needs.(Information } \\
\text { satisfaction) }\end{array}$ & .044 & .718 & -.043 & .103 & .196 & .067 \\
\hline $\begin{array}{l}\text { 19. I have succeeded in finding information } \\
\text { materials for my search. } \\
\text { (Material satisfaction) }\end{array}$ & .181 & .711 & -.029 & -.120 & .068 & -.062 \\
\hline $\begin{array}{l}\text { 7. I am good at using digital resources. (Use } \\
\text { of digital resources) }\end{array}$ & -.026 & .000 & .917 & .080 & -.085 & -.062 \\
\hline $\begin{array}{l}\text { 5. I know of the availability of digital } \\
\text { documents in the library. } \\
\text { (Awareness of current formats) }\end{array}$ & .077 & -.079 & .887 & -.025 & .045 & .161 \\
\hline $\begin{array}{l}\text { 11. I consult a librarian when I have } \\
\text { difficulty in finding information } \\
\text { (Utilization of assistance services) }\end{array}$ & -.030 & .050 & .039 & .785 & .038 & .036 \\
\hline $\begin{array}{l}\text { 12. Information literacy programs in the } \\
\text { library have increased my knowledge of how } \\
\text { to locate needed resources. } \\
\text { (Instruction of use) }\end{array}$ & .105 & .158 & .083 & .715 & -.218 & .077 \\
\hline $\begin{array}{l}\text { 6. Most of my searches are by author and or } \\
\text { title of a book. } \\
\text { (Way of selecting resources) }\end{array}$ & .193 & -.125 & -.191 & .379 & .300 & -.211 \\
\hline
\end{tabular}


Table 2 (continued)

\begin{tabular}{l}
$\begin{array}{l}\text { 16. Bibliographies, references, indexes and } \\
\text { abstracts are useful for me when gathering } \\
\text { information from the documents I find } \\
\text { (Navigational ability to information) }\end{array}$ \\
\hline $\begin{array}{l}\text { 14. Most materials I need are found } \\
\text { browsing through the bookshelves } \\
\text { (Patterns of discovering materials) }\end{array}$ \\
$\begin{array}{l}\text { 10. I know that the "Inter Library Loan" } \\
\text { service is available in my library. }\end{array}$ \\
$\begin{array}{l}\text { (Familiarity with library services) } \\
\text { 3. I come to the library to search for }\end{array}$ \\
$\begin{array}{l}\text { information recommended by } \\
\text { teachers.(Subject orientation) }\end{array}$
\end{tabular}

Extraction Method: Principal Component Analysis. Rotation Method: Promax with Kaiser Normalization.

Component 2 "Positive image of the library" has positive loadings on four variables: image of the information provider, Satisfaction on the collection, satisfaction on the found materials and satisfaction on the found information were mostly emphasized the image of the library. This component accounted for $7.7 \%$ of the variance in the dataset.

Component 3 "Familiarity with digital resources" accounted for $7.5 \%$ of the variance. It has strong coverage of digital resource usage such as awareness of current formats, and use of digital resources.

Component 4 "Usage of professional library assistance" accounted for $6.4 \%$ of the total variance. Three variables were related with the use of assistant services: instruction in use and navigational ability to materials were positively affected.

Component 5 "Browsing of indexes and library classification" is correlated with navigational ability to information and patterns of discovering materials. This component accounted for $5.7 \%$ of the total variance.

Component 6 "Readiness in searching" is correlated with three variables, utilization of assistance service, known item search and known method of searching, all of which represented prior understanding of the area of search. The three variables in this factor have common features of readiness for using the library, with their previous experience. It accounted for $5.1 \%$ of the total variance. The degree to which a searcher is familiar with (library services, prior experience of resource use and willingness to search for recommended readings) is interesting because the more knowledge the searcher possesses, the higher the possibility a searcher can achieve quick results, indicating that readiness in searching can affect a searcher's behaviour.

\section{Clustering of Students According to Principal Component Scores}

For each student, the values for the 20 variables (i.e. responses to the 20 questionnaire statements) were converted to values for the six principal components. Two-step cluster analysis (Blashfield \& Aldenderfer 1988) was carried out to cluster students based on their scores on the six principal components. The purpose was to identify clusters of students who had similar profiles (values for the six components) within each cluster, but distinct profiles 
between the clusters. In the first step, pre-clusters were formed using hierarchical clustering using Ward's method (Caliński \& Harabasz 1974). A non-hierarchical k-means clustering method was then applied to determine the final number of clusters. As a result, from the 222 students, four clusters of students were found. The four clusters can be characterized as follows:

1. Ineffective library users

2. Effective library users

3. Ineffective but positive users (i.e. ineffective users with a positive attitude towards the library)

4. Self-sufficient users.

The profiles of the four clusters are summarized graphically in Figure 1, in terms of their average values for the 6 principal components.

\section{DISCUSSION}

\section{Cluster 1: Ineffective Library Users}

The first cluster accounts for $23 \%$ (51) of the total 222 respondents. This cluster has negative average values for five components: proficient search capability, positive image of the library, familiarity with digital resources, usage of professional library assistance, and browsing of indexes and library classification. It has a positive average value for only the component of readiness in searching. Ineffective users were comprised of naïve medical students more than of social sciences students. Despite their ineffectiveness they were often seen day-to-day in the library.

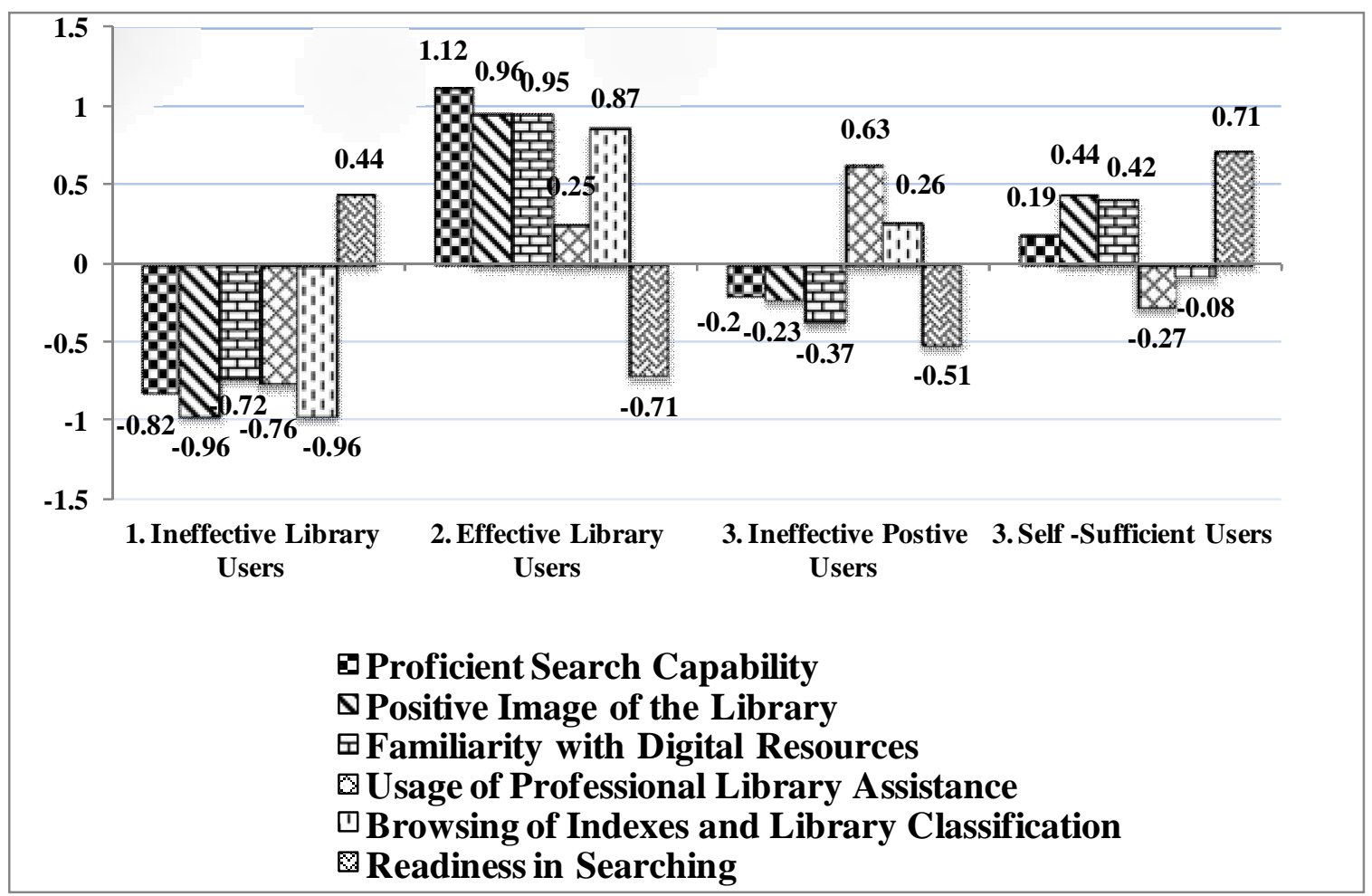

Figure 1. Profile of the four user clusters 


\section{Cluster 2: Effective Library Users}

The second cluster is the smallest of all the groups: $18 \%$ (40) of the respondents. The cluster has average positive scores for the components of proficient search capability, positive image of the library, familiarity with digital resources, usage of professional library assistance, browsing of indexes and library classification, and way of finding the materials. It has a negative score for readiness in searching. This is the only cluster with high positive scores for five components. Though this cluster lacks readiness in searching, it can be labelled as effective library users. The majority of this cluster was medical students who patronized the library frequently, rather than social sciences students.

\section{Cluster 3: Ineffective But Positive Users}

The largest cluster accounts for 32\% (71) of the respondents. The cluster has high positive values for usage of professional library assistance, and browsing of indexes and library classification. It has negative scores for readiness in searching, proficient search capability, positive image of the library, and familiarity with digital resources. The cluster seems to comprise traditional or conventional library users since they seek user assistance services and select books by casual browsing on the shelves rather than using modern searching techniques and strategies. They may use libraries for surface level information, but do not have an understanding of library systems for retrieving information. They lack knowledge and skills related to the components of readiness in searching, familiarity with digital resources, positive image of the library, and proficient search capability, which greatly limits them in the process of library use. The majority of this cluster was junior students in the social sciences.

\section{Cluster 4: Self-Sufficient Users}

The last cluster makes up 27\% (60) of the respondents. It has positive values for four components: readiness in searching, positive image of the library, familiarity with digital resources and proficient search capability. This cluster has negative scores for the components usage of professional library assistance and browsing of indexes and library classification. The cluster members do in-depth searching using library system search tools, but rarely consult librarians or do casual browsing at the shelves. The majority of this group consisted of juniors.

\section{CONCLUSION}

Analysing the segment of library users based on the profile of library use, knowledge and perceptions of undergraduate students is vital to understanding how academic libraries are being used by students and the kinds of search behaviour they exhibit. Different profiles of behaviours emerged from multiple aspects of library use/knowledge/perceptions of the students. As universities, libraries and students have become increasingly diverse, the usage of academic libraries is also becoming more diversified. The twenty aspects of library use/knowledge/perceptions were summarized by six components using principal components analysis. Subsequently, four clusters of students, who had similar profiles of library use/knowledge/perceptions, were derived. In other words it is possible to identify factors of students' library use, knowledge and perceptions, and to identify student groups with similar profiles in the scores for these factors. 
Future work can investigate how the library can tailor its services and resources to these four clusters of users, with different needs, behaviours, knowledge, and perceptions. A more in-depth questionnaire addressing a bigger range of library use activities can also be explored.

\section{REFERENCES}

Blashfield, R. K., \& Aldenderfer, M. S. (1988). The methods and problems of cluster analysis. In Handbook of multivariate experimental psychology (pp. 447-473). Berlin: Springer.

Caliński, T., \& Harabasz, J. (1974). A dendrite method for cluster analysis. Communications in Statistics-Theory and Methods, 3(1), 1-27.

Goodall, D., \& Pattern, D. (2011). Academic library non/low use and undergraduate student achievement: A preliminary report of research in progress. Library Management, 32(3), 159-170.

Hiller, S. (2002). How different are they? A comparison by academic area of library use, priorities, and information needs at the university of Washington. Issues in Science and Technology Librarianship, 33(33).

Nagata, H., Toda, A., \& Kytömäki, P. (2007). Students' patterns of library use and their learning outcomes. Paper presented at the Evidence-Based Library \& Information Practice 4th International Conference, Durham, North Carolina.

Palmer, J. (1991). Scientists and information: I. using cluster analysis to identify information style. Journal of Documentation, 47(2), 105-129.

Ruthven, I., Baillie, M., \& Elsweiler, D. (2007). The relative effects of knowledge, interest and confidence in assessing relevance. Journal of Documentation, 63(4), 482-504.

Soria, K. M., Fransen, J., \& Nackerud, S. (2013). Library use and undergraduate student outcomes: New evidence for students' retention and academic success. Portal:

Libraries and the Academy, 13(2), 147-164.

Stone, G., \& Collins, E. (2013). Library usage and demographic characteristics of undergraduate students in a UK university. Performance Measurement and Metrics, 14(1), 25-35.

Varga-Atkins, T., \& Ashcroft, L. (2004). Information skills of undergraduate business students-a comparison of UK and international students. Library Management, 25(1/2), $39-55$.

Whitmire, E. (2001). A longitudinal study of undergraduates' academic library experiences. Journal of Academic Librarianship, 27(5), 379-385. 